\title{
Analysis Corrected Performance Ratio on Photovoltaic Through Four Temperature Cell Model
}

\author{
Rio Agustian Fajarin ${ }^{1}$, Eko Adhi Setiawan ${ }^{* 1,2}$ \\ ${ }^{1}$ Department of Electrical Engineering, Faculty of Engineering, Universitas Indonesia, \\ Kampus Baru UI Depok, Depok 16424, Indonesia \\ ${ }^{2}$ Tropical Renewable Energy Center (TREC), Faculty of Engineering, Universitas Indonesia, \\ Kampus Baru UI Depok, Depok 16424, Indonesia
}

\begin{abstract}
To measure the performance of photovoltaic system, performance ratio is a common indicator to used. However, the performance ratio calculation is based on various methods to determine the value of photovoltaic temperature. The modelling used in this research is sandia, Ross and Smokler, Schott and Faiman modeling. Each model have different coefficient values from each others. Thus, each modelling has different performance ratio values that will be compared between others. From this comparison we will get the best modelling that closest to the real conditions.
\end{abstract}

\section{Introduction}

Indonesia is a country in a tropical climate where has enormous renewable energy potential to be utilized. This solar energy or photovoltaic system depends on other influences both from the side of the system and from outside the system. This is what influences the evaluation process of the performance of the photovoltaic system used.

One of the most important parameters in the evaluation of perfomance ratio system in photovoltaics can be known through the temperature cell model. This model is influenced by photovoltaic materials, absorption and dissipation, photovoltaic type, configuration, weather conditions, local conditions of installation, the magnitude of solar radiation, ambient temperature, and wind speed.

From several temperature models of photovoltaic module, four modeling is used. Those models are Sandia modeling, Ross and Smokler modeling (1986), Schott Modeling (1985), and Faiman modeling.The reason for choosing these models is because they have maximum limit of two variables coefficient.

Each model will find the value of its coefficient. Then, these models can be used to determine Corrected Performance Ratio value and compare to the Corrected Performance Ratio from real data. From this comparison we will get the best temperature model that can determine corrected performance ratio value that closest to corrected performance ratio value from real data.

\section{Method}

In this study, the solar irradiation data was taken from Shah Alam area, Selangor, Malaysia.

\subsection{IEC 61724 Methodology}

According to IEC 61724 Standard, performance ratio is ratio between final yield and reference yield of photovoltaic system.

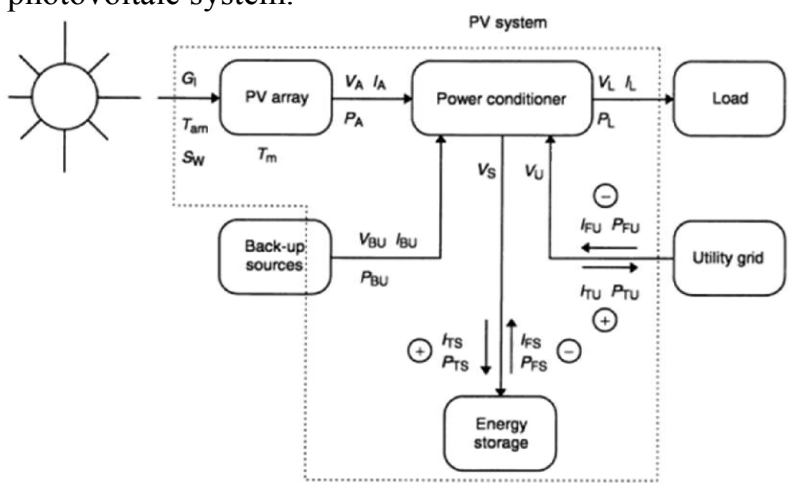

Fig 1. Parameters to be measured in real time (adopted from IEC 61724)

The following is several equations that used to calculate performance ratio :

$$
\begin{gathered}
\text { Performance Ratio }(\boldsymbol{R p})=\boldsymbol{Y}_{\boldsymbol{f}} / \boldsymbol{Y}_{r} \\
\boldsymbol{Y}_{\boldsymbol{f}}=\boldsymbol{Y}_{\boldsymbol{A}} \cdot \boldsymbol{\eta}_{\mathrm{LOAD}} \\
\boldsymbol{Y}_{\boldsymbol{A}}=\frac{\boldsymbol{E}_{A, \boldsymbol{d}}}{\boldsymbol{P}_{\mathbf{0}}}=\boldsymbol{\tau} \mathbf{x} \frac{\left(\boldsymbol{\Sigma}_{\text {day }} \boldsymbol{P}_{A}\right)}{\boldsymbol{P}_{\mathbf{0}}}
\end{gathered}
$$

\footnotetext{
Corresponding author: rio.agustian@ui.ac.id.org
} 


$$
\eta_{\mathrm{LOAD}}=\frac{E_{U S E, \tau}}{E_{\text {in, },}}
$$

Where:

$$
\boldsymbol{Y}_{r}=\boldsymbol{\tau}_{\mathrm{r}} \mathbf{x} \frac{\left(\Sigma_{\mathrm{day}} \mathrm{G}_{\mathrm{I}}\right)}{\mathrm{G}_{\mathrm{I}, \mathrm{ref}}}
$$

- $\boldsymbol{R}_{p}$ : performance ratio

- $\boldsymbol{Y}_{f}$ : final yield

- $\boldsymbol{Y}_{\boldsymbol{r}}$ : reference yield

- $\boldsymbol{Y}_{\boldsymbol{A}}$ : array yield

- $\boldsymbol{E}_{A, d}$ : the daily array energy output

- $\boldsymbol{P}_{0}$ : rated output power, $\mathrm{kW}$ of installed PV array

- $\eta_{\text {LOAD }}$ : load efficiency

- $\mathbf{E}_{\mathrm{USE}, \tau}$ : total system input energy

- $\mathbf{E}_{\mathbf{i n}, \tau}$ : total system output energy

- $\boldsymbol{\tau}_{\mathrm{r}} \times\left(\sum_{\text {day }} \mathbf{G}_{\mathbf{I}}\right)$ : total daily in-plane irradiation

- $\mathbf{G}_{\mathbf{I}, \text { ref }}$ : module's reference in-plane irradiance, $\mathbf{G}_{\mathbf{I}, \mathrm{ref}}=1000 \mathrm{~W} / \mathrm{m}^{2}$

These equations, applied in both on-grid and off-grid system. However in on-grid system, the load efficiency can be ignored because the system directly connected to utility grid. So we can view performance ratio as ratio as the actual AC energy delivered from the system to nominal (theoretical) energy from rated output power [2].

\subsection{Weather-Corrected Performance Ratio}

Although performance ratio is an indicator that globally accepted, it value is susceptible to weather factors especially temperature that affect its value and cause variations in its value. NREL consider this factor and propose a method to reduce this effect. This calculation method is weather-corrected performance ratio.

The following is the result of the method from simulation by figure 2 .

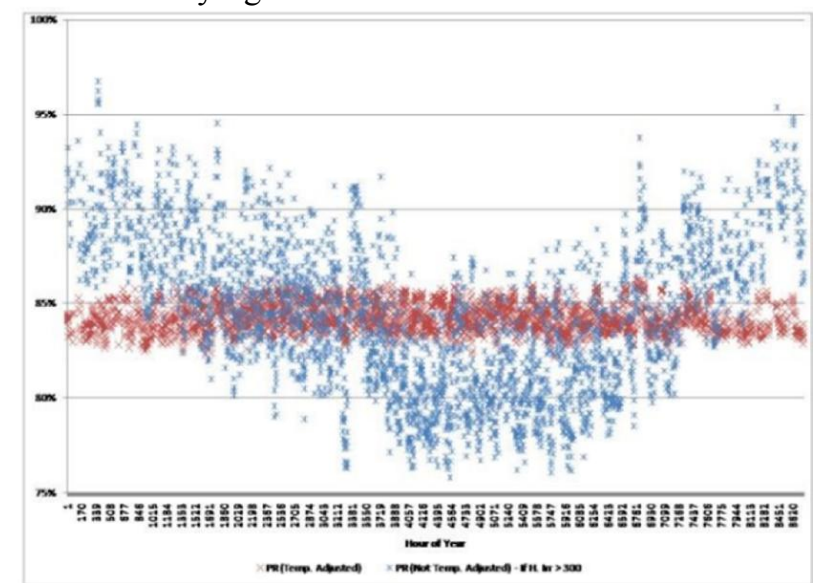

Figure 2 Corrected and uncorrected calculated for each hour of the year for the same simulation described

$$
P \boldsymbol{R}_{\text {corr }}=\frac{\Sigma_{i} E N_{A C, i}}{\Sigma_{i}\left[P_{S T C}\left(\frac{G_{P O A, i}}{G_{S T C}}\right)\left(1-\frac{\delta}{100}\left(T_{\text {cell,typ }, \text { avg }}-T_{\text {cell }, i}\right)\right)\right]}
$$

- $\quad \mathbf{P R}_{\text {corr }}$ : weather-corrected performance ratio

- $\mathbf{E N}_{\mathrm{AC}}$ : the measured AC electrical generation (kW)

- $\quad$ P $_{\text {STC }}$ : the summation of installed modules' power rating from flash test data $(\mathrm{kW})$

- $\mathbf{G}_{\mathbf{P O A}}$ : the measured plane of array (POA) irradiance $\left(\mathrm{kW} / \mathrm{m}^{2}\right)$

- $\mathbf{G}_{\mathrm{STC}}$ : irradiance at STC, $\mathrm{G}_{\mathrm{STC}}=1 \mathrm{~kW} / \mathrm{m}^{2}$

- $\quad \mathbf{T}_{\text {cell_typ_avg }}$ : cell temperature typical average from a year

- $\mathbf{T}_{\text {cell_ }}$ : cell temperature

- $\boldsymbol{\delta}$ : temperature coefficient for power $\left(\% /{ }^{\circ} \mathrm{C}\right)$ at STC

However in real operating condition the value of temperature coefficient for power $(\delta)$ varies in different level of irradiance of array [4].

\subsection{Type of Modeling}

Allows various modeling to get the value of the temperature cell. In this study using sandia modeling, ross modeling, schott modeling, and modeling faiman.

Here are four models used.

\subsubsection{Sandia Model}

In SANDIA modeling, the value coefficients of parameters $a$ and $b$ are where this value depends on the module construction and the material and configuration of the module installation. To searchin back temperature module :

$$
\mathbf{T}_{\mathrm{m}}=\mathbf{E} \cdot\left\{\mathrm{e}^{\mathrm{a}+\mathrm{b} \cdot \mathrm{WS}}\right\}+\mathbf{T}_{\mathrm{a}}
$$

While to get the value of coefficient $a$ and coefficient $b$ use linear regression with equation:

$$
\mathbf{Y}=\ln \left(\mathbf{T}_{\mathrm{m}}-\mathbf{T}_{\mathrm{a}}\right) / \mathbf{E}
$$

Then, to find the value of temperature cell

$$
\mathbf{T}_{\mathrm{c}}=\mathbf{T}_{\mathrm{m}}+\left(\mathbf{E} / \mathbf{E}_{0}\right) . \mathbf{T}
$$

\section{Information:}

Tm : Rear surface module temperature

$\mathrm{T}_{\mathrm{a}}$ : Temperature of ambient air

$\mathrm{T}_{\mathrm{C}}:$ Temperature Cell

WS : Wind speed

a : The temperature limit coefficient over the module at low wind speed and high solar radiation

b :The coefficient at which the module's temperature level drops when the wind speed is high

E : Solar radiation on the module

$\mathrm{E}_{0}$ : Solar reference radiation on module $(1000 \mathrm{~W} /$ $\mathrm{m} 2) 2$

\subsubsection{Ross and Smokler Model ( 1986 )}

$$
T_{c}=T_{a}+0.035 . G_{t}
$$

\section{Information:}


- $\mathrm{T}_{\mathrm{C}}$ : Temperature Cell

- $\mathrm{T}_{\mathrm{a}}:$ Temperature of ambient air

- $\mathrm{G}_{\mathrm{t}}$ : Solar radiation on the module

\subsubsection{Schott Mode}

Information:

$$
T_{c}=T_{a}+0.028 \cdot G_{t}-1
$$

- $\mathrm{T}_{\mathrm{C}}$ : Temperature $\mathrm{C}$

- $\mathrm{G}_{\mathrm{t}}$ : Solar radiation on the $\operatorname{modulT}_{\mathrm{a}}$ : Temperature of ambient air

- $\mathrm{G}_{\mathrm{t}}$ : Solar radiation on the module

\subsubsection{Faiman Model}

$$
T_{m}=T_{a}+\operatorname{EPOA} /\left(u_{0}+u_{1} \cdot W S\right)
$$

\section{Information:}

- $\mathrm{T}_{\mathrm{C}}:$ Temperature Cell

- $\mathrm{T}_{\mathrm{a}}:$ Temperature of ambient air

- $\mathrm{E}_{\mathrm{poa}}$ : Solar radiation on the module

- WS : Wind speed

- $\mathrm{U}_{0}$ : Constant heat transfer $\left(\mathrm{W} / \mathrm{m}^{2} \mathrm{~K}\right)$

- $\mathrm{U}_{1}$ : Convective heat transfer $\left(\mathrm{W} / \mathrm{m}^{2} \mathrm{~K}\right)$

\subsection{Photovoltaic Systems}

Here is the on-grid photovoltaic system in tropics that used to this research based table 1 .

\begin{tabular}{|c|c|c|c|c|c|c|c|c|}
\hline \multirow[b]{2}{*}{00} & \multirow{2}{*}{$\begin{array}{l}\text { Kode } \\
\text { Nama }\end{array}$} & \multirow{2}{*}{$\begin{array}{c}\text { Nama } \\
\text { Sistem } \\
\text { Fotovoltaik }\end{array}$} & \multirow{2}{*}{ Negara } & \multicolumn{2}{|c|}{ Koordinat (Desimal) } & \multirow{2}{*}{$\begin{array}{c}\text { Jenis } \\
\text { Fotovoltaik }\end{array}$} & \multirow{2}{*}{$\begin{array}{c}\text { Kapasitas } \\
\text { Daya }\end{array}$} & \multirow{2}{*}{ Data Terekam } \\
\hline & & & & Lintang & Bujur & & & \\
\hline 1 & $\begin{array}{l}\text { Mono- } \\
\text { UiTM } \\
\end{array}$ & $\begin{array}{l}\text { GIMA- } \\
\text { GERC }\end{array}$ & Malaysia & 3.068734 & 101.4969 & Monokristalin & $\begin{array}{l}9,000 \\
k W_{p}\end{array}$ & $\begin{array}{c}\text { 1 Juli } 2017-31 \\
\text { Juli } 2017\end{array}$ \\
\hline 2 & $\begin{array}{l}\text { Poly- } \\
\text { UirM }\end{array}$ & $\begin{array}{c}\text { UiTM- } \\
\text { GERC } \\
\text { Poly } \\
\text { System }\end{array}$ & Malaysia & 3.068734 & 101.4969 & Polikristalin & $\begin{array}{l}5,405 \\
k W_{p}\end{array}$ & $\begin{array}{l}\text { 1 Juli } 2017-31 \\
\text { Juli } 2017\end{array}$ \\
\hline 3 & $\begin{array}{l}\text { Thin- } \\
\text { UirM }\end{array}$ & \begin{tabular}{|c|} 
UiTM- \\
GERC \\
Thin Film \\
\end{tabular} & Malaysia & 3.068734 & 101.4969 & $\begin{array}{c}\text { Amorfus } \\
\text { (Thin-Film) }\end{array}$ & $\begin{array}{l}0,900 \\
\mathrm{~kW}_{\mathrm{p}}\end{array}$ & $\begin{array}{c}2 \text { Juni } 2017-21 \\
\text { Juni } 2017\end{array}$ \\
\hline
\end{tabular}

Table 1 Characteristics photovoltaic

\section{Result and Discussion}

Firstly, before we can calculate the correction ratio performance of each model then from each model is searched the first value coefficient contained in each modeling.

Table 2 Modeling by two variables

\begin{tabular}{|l|c|c|}
\hline & \multicolumn{2}{|c|}{ coefficient value } \\
\hline \multicolumn{1}{|c|}{ Modeling } & $\mathrm{a}$ & $\mathrm{b}$ \\
\hline Sandia & 0.00126 & -0.0004 \\
\hline Faiman & 29.851 & -4.751 \\
\hline
\end{tabular}

This modeling is a model that has two variables, namely a coefficient that describes the upper temperature limit of the module when low wind speed and high solar radiation and coefficient $b$ that describes the value when the module temperature level drops at high wind speed, this value is obtained from linear regression.
Table 3 Modeling by one variables

\begin{tabular}{|l|l|}
\hline \multicolumn{1}{|c|}{ Modeling } & $\begin{array}{c}\text { coefficient } \\
\text { value }\end{array}$ \\
\hline Ross \& Smokler & 0.0511 \\
\hline Scott & 0.0567 \\
\hline
\end{tabular}

Whereas, in Ross \& Smokler modeling and modeling Scott only has coefficient values where this value is the result of the mean value divided by the amount of the data..

\subsection{Mono System}

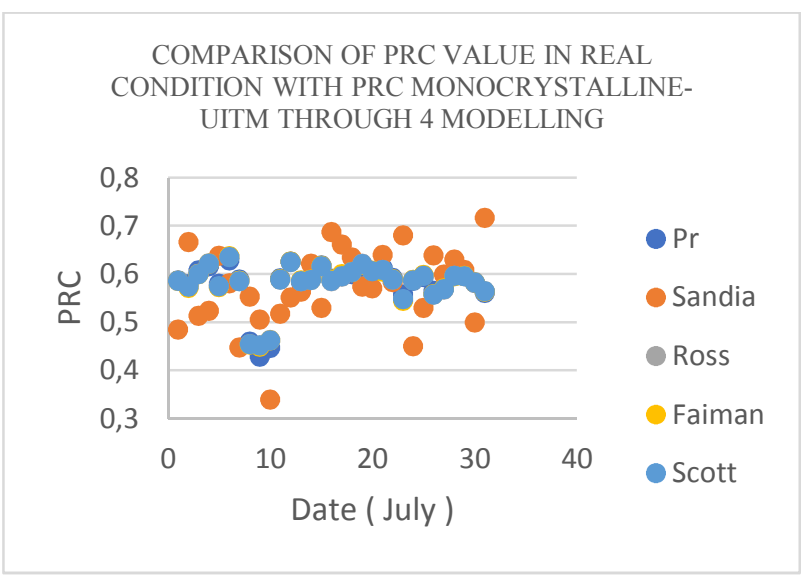

Figure 3 Comparison PRC value Monocrystalline in real condition vs 4 modeling

In the Mono system by figure 3, the best modeling values are faiman, ross, schott and sandia. This is because the absolute value of the absolute error is small at 0.0086 . As for ross of 0.0093 , for Scott of 0.0104 and for sandia of 0.1766

\subsection{Poli System}

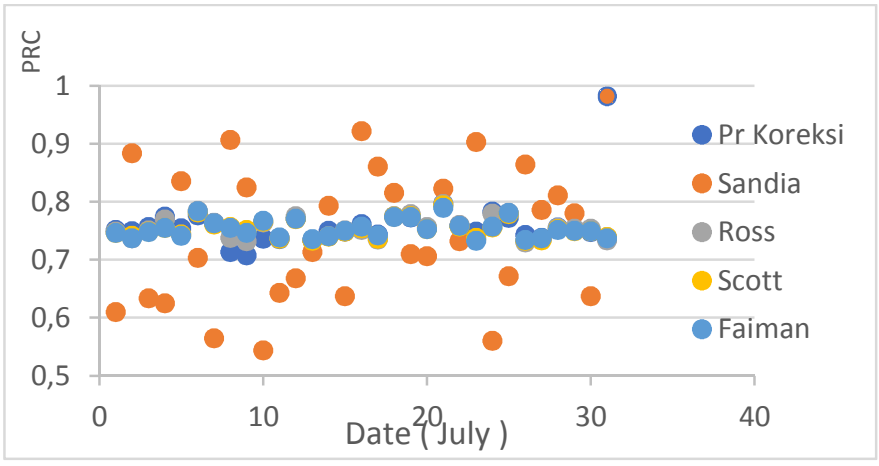

Figure 4 Comparison PRC value Polycrystalline in real condition vs 4 modeling

In the poly system by figure 4 , the best modeling model is modeled by faiman, ross and smokler, schott, and sandia. The absolute value of these errors are 0.0092 , $0.010,0.012$ and 0.143 , respectively. 
3.2 Thin System

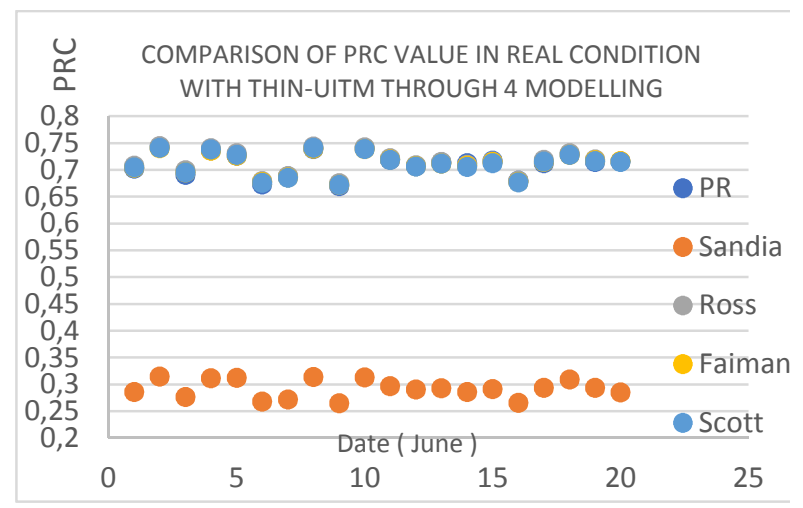

Figure 5 Comparison PRC value Thin in real condition vs 4 modeling

In thin system by figure 5 , the best modeling value is faiman, then schott, ross and last sandia. The absolute value of erros in sequence is $0.0025,0.0033,0.0051$ and 0.589 . The value of sandia is very different from the true value because the calculation is difficult and requires a lot of variables.

\section{Conclusion}

This paper discusses the calculation of correction factor perfomance ratio of various models to compare and get the modeling value closest to the value under the actual conditions. In the search phase correction factor using coefficient value calculated in advance according to existing procedures. The results of this study illustrate that in rosse \& smoker modeling, Schott and faiman indicate that this modeling is the best model. This is because the value between the correction ratio perfomance ratio value on the actual conditions is very close and has a small erro factor. In addition, this model requires only a few variables that affect only. In contrast, in sandia modeling which is the worst model for all photovoltaics, this is because the error factor is quite different from the actual conditions especially in thin photovoltaic. This is because the data processing is quite complicated and requires many variables.

The authors would like to thank this work was supported and funded by"Hibah Penelitian dan Penulisan Tugas Akhir UI".

\section{References}

1. King D.L, Boyson, Kratochvil J.A “ Photovoltaic Array Perfomance Model “, Sandia Report, 2004

2. PV Perfomance Modeling Collaborative, Website https://pvpmc.sandia.gov/

3. Jakhrani A, Othman, " Comparison of solar photovoltaic module Temperature Model “ ,World Applied sciences journal, 2011

4. Performance Ratio-Quality Factor for the PV plantsSMA, Web. 22 May 2018. Accessed from:
〈http://files.sma.de/dl/7680/PerfratioUEN100810.pdf . 